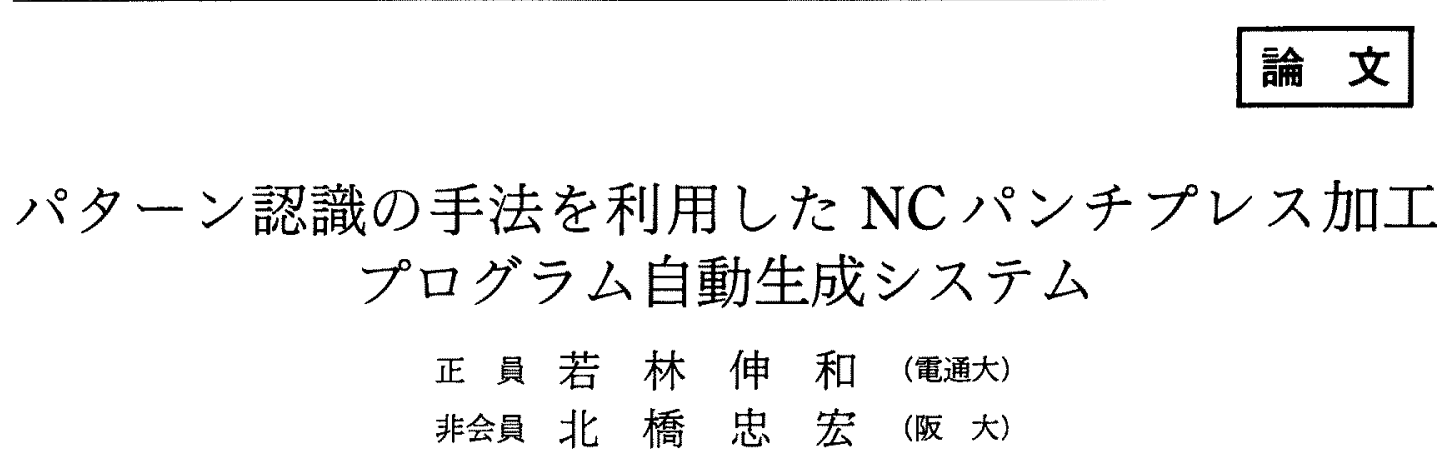

\title{
Automatic Generation System for Making NC Punch Press Programs using Pattern Recognition Technique
}

Nobukazu Wakabayashi, Member (University of Electro-Communications), Tadahiro Kitahashi, Non-member (Osaka University)

An automatic program generation system for $\mathrm{NC}$ punch press machine is proposed. NC programs to control machine tools can be generated automatically by the system according to the data described in the design drawing of final products.

In this system, silhouette decomposition procedure which is one of pattern recognition techniques is employed to recognize the drawing. The procedure is applied to decompose a complex shaped hole in the design drawing into punch primitives, where the shaped hole and the punch primitives correspond to the overlapped silhouette and the discrete components of it, respectively.

The outline of the developed silhouette decomposition procedure and automatic program generation system is given.

\section{キーワード：NC 工作機械，CAD/CAM システム，シルエット分離，プログラム自動生成}

\section{1.まえがき}

高精度の金属加工を行うものとして NC（Numerical Control) 工作機械を利用した板金加工がある。 NC工作機械は，従来の機械のように熟練者による操 作は必要とせず，プログラムを与えることにより機械 を制御する方式をとっているので，いったんプログラ 厶を作成すれば，一定品質の反復加工が可能である。 $\mathrm{NC}$ 機械を用いた生産では，設計図面の作成，NCプ ログラムの作成，工作機械による加工という手順をふ んで製品ができあかる。近年 CADの普及により図面 の作成段階では自動化が進んでいる。しかし，その図 面に従って実際に加工を行うためのNCプログラム は，製品仕様としての製図図面を見ながら手作業で行 つて㧍り，仕様が異なるとそのつどプログラミング作 業が必要である。このことが，NC加工のボトルネッ クとなりつつあり，近年の多品種少量生産やモデルチ エンジの期間短綰などに対応したオートメーションを
可能にするためには，プログラム作成過程の自動化が 切望される。仕様としてCAD 図面データを利用し， 自動的に加工プログラムを生成するシステムが実現て きればソフトウェア生産性の向上が期待できる。

NC加工プログラムの作成は，（1）設計図面の認 識, (2) コードの作成, という二つの作業に大別され る。本論文で述べる NC加エプログラム自動生成シ ステムでは，（1）の部分に，構成的手法を用いた重複 二次元図形の分離手法を用いている。ここていう棈成 的手法とは，図形の構成要素である輪郭線および重複 により隠ぺいされた内部輸郭線をいったん可能な限り 細分し，これを合理的な制約を課して再構成すること を通じて分離可能な図形の候補を生成し，そのなかか ら与えられた条件を满足するものを選択するという方 法を意味している。本システムにおける図面認識とい う課題では, 後続のコード生成における加工手順など の決定のための前処理として図面の鮸識・理解を位置 づけることができ, 後続処理に適した認識結果が要求 
される。更に入力として CAD システムの出カデータ の利用を仮定できる。このように限定された領域を対 象とすることにより，一般的なシルエットを対象とし た場合よりも認識手続きを簡素化できると期待され る。提案する手法は工学的な応用に限定し, 結果の利 用に重点を置くものである。

一方，(1)の部分における適切な図面認識は，（2） のコード作成の部分における比較的単純な規則の組合 せによるプログラムコード生成を可能にする。本シス テムでは，そのような幾つかの加工に関する規則を手 続的に記述し，これを利用して加工方法の選択を行 い，プログラムを生成する。また，加工の順序も手続 的な規則の利用により決定する。これは最終的な製品 の加工精度や加工に要する時間などを左右する重要な 要素である。

次章以降では, システム全体の概要, 重複分離手続 きの概要，上記 (1)，(2)にそれぞれ対応するシルエ ット分離モジュールおよびプログラム生成モジュー ル，および併せて作成した NC加エシミュレーショ ンッールについて説明し，実行結果とともに示す。シ ミュレーションツールは単体でもプログラムのデバッ グ作業などに利用できるよう配慮して作成した。

\section{2. システムの概要}

\section{〈2・1〉 NC 加エと G コードプログラミング}

本研究て対象として取り上げたのは NCタレット パンチプレス工作機械(NCT) と呼ばれるものである。 これは, 二次元の穴開け加工を行うもので, 板状の金 属材料を各種形状の工具で打ち拔くことにより，様々 な形状の穴を開けることができる。打抜きに使用する

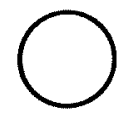

(a) 丸

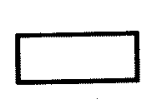

(b) 長角

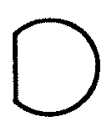

(d) 長丸 (e) シンダルD (f $)$
図 1 標準工具の形状

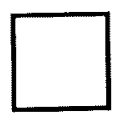

(c) 角

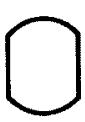

f) ダフルD
Fig. 1. Shapes of standard tools.

\begin{tabular}{|l|}
\hline G92X1000.0Y100.0 \\
G90X100.0Y200.0T102 \\
G90X200.0Y200.0 \\
G91X50.0Y-50.0T203 \\
G50
\end{tabular}

図 $2 \mathrm{G} コ$ コートプログラムの例

Fig. 2. An example of $\mathrm{G}$-code program.
工具には種々の形状および寸法が用意され，タレット と呼ばれるテーブルに一度に複数個の工具を取り付け ることができる。タレットを回転させることで打抜き に用いる工具が選択可能なため, 工具交換なしに種々 の形状掞よび大きさの穴を連続的に加工することがて きる。NCTでの加工に用いられる標準的な工具の形 状は図1に示すものに限定されている。

NCT を制御するためのコードとしては， G コード と呼ばれるプログラミング言語仕様が使われている。 図2にGコードプログラムの例を示す。Gコードプ ログラムの 1 行は通常 1 回の打抜き動作に対応してお り，“G”に続く2桁の数字で表されたパンチ命令，打 ち抜く位置の $X$ および $Y$ 座標値, そして“T”に続く 3 析の数字で表された，打抜きに用いる工具がタレッ 卜上に取り付けられている位置の情報が記述される。

〈2・2〉 NCプログラム自動生成の手順従来の NCT 用 Gコードプログラミングにおいては，熟練し たプログラマはまず製品の仕様である設計図面を読み 取り, 複雑な形状の穴の場合には, 標準工具をどのよ うに組み合わせればその形状が加工できるかを考え て, 複数回の打抜きに対応させるように与えられた形 状を分解する。その後, 加工方法を考えて工具を選択 し，加工精度を良く，かつ加工時間を短くするよう考 慮して加工順序を決定し最終的に G コードを作成す る。このようにプログラマは図面の認識・分解, G ードの生成, 順序の決定という段階をふんでプログラ ミングを行っている。本システムにおいても，おおむ ねこの手続きに従ってNCプログラム自動生成を行 うことを考え，その手順は図 3 に示すとおりとする。

〈2・3〉 シルエット分離手法の応用 NCTによ る加工ては, 例えば図 4（a）のような形状の穴開けを 行う場合の加工方法としては，(b)図のように複数の

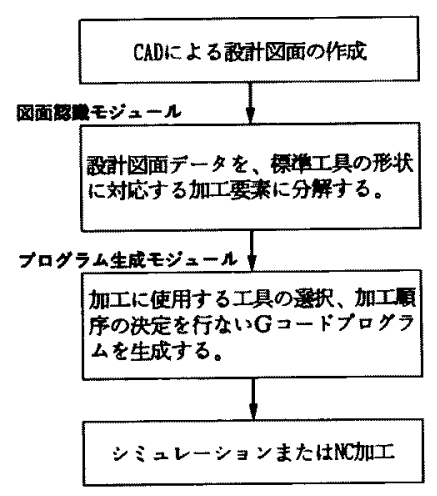

図 3 NCプログラムの生成手順

Fig. 3. Sequence of automatic G-code generation. 


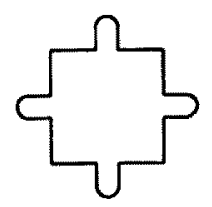

(a) 加工すぬき穴の形状

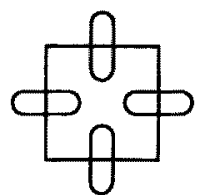

(b) (a)国の形状に対するパンチ
図 4 パンチプレス加工の例

Fig. 4. An example shape of hole in punch press machining.

加工要素（打抜き）を組合せることによって所望の形 状を得る。このような人間のプログラマが行っていた 図面の認識・理解を自動的に行うためには，CADによ って作成された設計図面加ら形状を諗識し，加工要素 に分解する処理が必要である。この処理にシルエット 分離手続きを利用する。一つの工具を成分図形とみな せば，複数の加工要素で実現されるようなできがり 製品中の複雑な穴の形状は，成分図形が重複してでき た輪郭線図形（シルエット）とみなすことができる。 従って, 穴の形状を表した CAD データを入力し重複 分離を行えば，加工要素に分解された図形デー夕を得 ることができる。

\section{3. シルエット分離手続き}

重複した物体像から各物体を分㓲隹・認識する問題は 視覚心理モデルの作成から産業応用を想定したものま

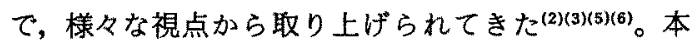
諭文で提案する手法は，産業応用に限定し結果の利用 に重点を固くものである。

本手法では, NC加工のための図面認識への応用を 考慮し，対象を直線执よび円弧のみの組合せからなる 図形に限定する。また，入力はCADシステムなどに よって作成された線図形デー夕を想定し, 各頂点の座 標値が与えられているものとする。入力は，䙡数の凸 図形が重複して構成された輪郭線(シルエット)図形と する。従って，成分四形は山四形であると仮定して分 離を行う。図 5 に重複分離手法の処理の流れを示す。

この手法は二次元の形状を復元する問題にもかかわ らず，一次元に関する制約のみを用いることにより処 理を行うことができるという特徽がある。換言すれ ば，成分図形の二次元形状についての性質に関する規 則の記述は必要なく，成分図形を構成する辺に関する 性質，すなかち一次元での幾つかの規則を記述すれば よい。本手続きの主要な処理はそのような規則を利用 して成分図形の辺となり得る要素(辺候補)を生成し, その後边候補のみの組合せで構成される閏図形を単純 に抽出する。以下，各段階における処理を説明する。

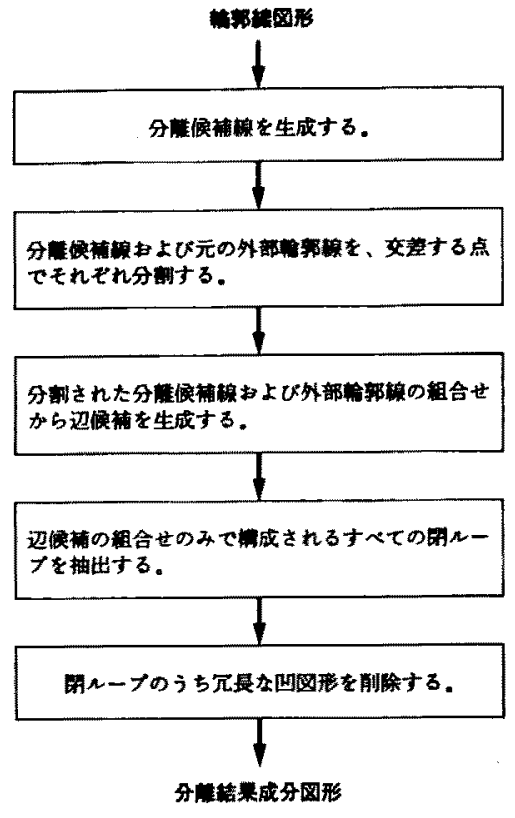

図 5 シルエット分離処理の流れ

Fig. 5. Overall flow of the decomposition process.

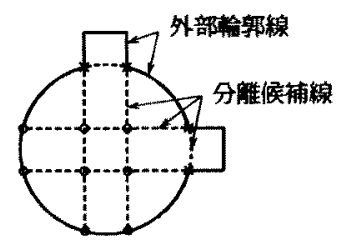

図 6 分離候補線の生成と分割

Fig.6. Extrapolation and segmentation of "separation lines".

〈3・1〉分離候補線の生成および分割重複によ って隠ぺいされた内部輪郭線を“分離候補線”と呼 ぶ。外部翰郭線図形の山頂点加ら，外部輪部線の性質 を有しかつ図形の内側を外部輪郭線に交わるまで延長 した線を分離候補線として生成する。すなわち，図 6 に示すように直線は直線て，円弧は円弧て延長する。 同図に×印で示した点が分雕候補線の始点である。

次に，分䧺候補線同士が交差する場合はその交点で 各分離候補線を分割し，独立した線分とする。また外 部輪部線が分離候福線によって分割される锡合は元の 輪郭線を分割した輪郭線に固換する。図6中にの印で 示した点が分割された点である。

〈3-2〉辺候補の生成重複図形の分部結果とし て得られる成分図形は，上記のように細分された線分 
の組み合わせによって構成される。このような成分図形 の辺になる可能性のある線を“㲽候補”と呼ぶ。また， 一直線上にある外部輪郭線および分離候補線を連結す ることによってできる最も長い線分を“複合線分” (図 7 中, 線分 $A F, P W$ ) と呼び, 複合線分を構成 する線分のうち, 複合線分の端点を含む線分を“終端 線分" (図 7 中, 線分 $A B, E F, P Q, U W$ ) と呼ぶ。 複合線分から辺候補を生成するためのモデルを図 7 に提案する。このモデルを利用すれば，前節で細分さ れた外部輪郭線と分離候補線の端点に関する条件のみ で辺候補生成の規則を表すことができる。図 7 に示す ようにモデルは二つの場合に大別される。

図 7(a)のように, 終端線分のいずれか一方が分離 候補線である,すなわちモデル1の場合には, 複合線 分 $A F$ 上の外部輪郭線（図中実線）枋上び分離候補 線（図中破線）の各端点 $A \sim F$ を次の五つのタイプ に分類する。

タイプI：終端線分が分離候補線側である複合線 分の端点 $(F)$

タイプII：終端線分が外部輪郭線側である複合線 分の端点 $(A)$

タイプIII：外部輪郭線と分離候補線が接する点 (D)

タイプIV：分雕候補線間の点 $(E)$

タイプV: 外部輪郭線間の点 $(B, C)$

図 7 (b)のように, 両終端線分がともに外部輪郭線

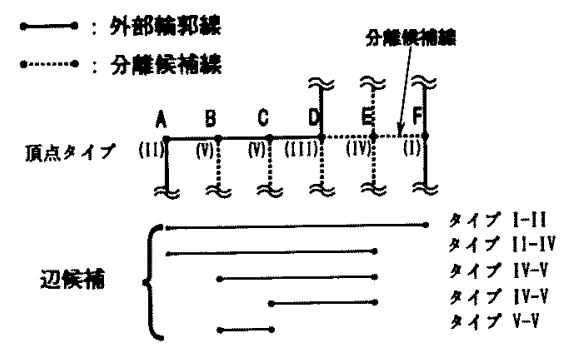

（a）終端線分のうち一方が分盛候補線の堨合(モデル1)

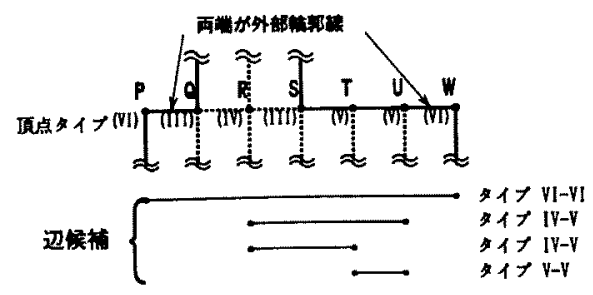

（b）終端線分が両方とも外部輪影線の場合(モデル2)

図 7 辺候補生成のモデル

Fig. 7. Permissible line patterns for occluded edge recovery.
である，すなわちモデル 2 の場合には, 複合線分 $P W$ 上の点の多くはモデル 1 の場合と同様にタイプIII V に分類されるが，複合線分の両端点は新たなタイプVI とする。

$$
\text { タイプVI:始点および終点 }(P, W)
$$

辺候補は，成分図形は凸図形であり成分図形の輪郭 線は頂点以外の部分では滑らかであるという仮定に基 づき，二つのモデルに対し図 7 中に示した組合せのみ が許容され，生成規則は以下のようになる。

モデル1〔( a )図〕の場合, 頂点タイプ

$$
\text { I-II, II-IV, IV-V, V-V }
$$

の対よりなるすべての線分を辺候補として生成する。 (a)図の例では図示した 5 個の辺候補が生成される。 モデル2[(b)図)の場合, 頂点タイプ

$\mathrm{VI}-\mathrm{VI}, \mathrm{IV}-\mathrm{V}, \mathrm{V}-\mathrm{V}$

を結ぶ線分を辺候補として生成する。(b)図の例では 4 個の辺候補が生成される。なお，簡単のため図 $7 て ゙$ は直線の例で説明したが, 円弧の場合も同様の規則で 辺候補を生成する。

〈3・3〉閉ループの抽出 上述の処理によって得 られた辺候補の組から，閉ループをなす図形をすべて 抽出する。閉ループとは, 辺候補の端点のうちある一 点から開始し, 辺候補のみを追跡することによって元 の点に戻ってくることができる閉じた図形で，一つの ループを構成する辺候補は互いに交差してはならな い。図6の入力を処理した結果を図 8 に示す。この例 では 4 個の閉図形が抽出された。

抽出された結果の閉図形には，圥長な図形が含まれ ている場合がある。ここでいう圥長とは, 他の閉図形 のいずれかの辺にその図形の辺がすべて含まれている もの，換言すれば，その図形を分離結果から削除して も残りの図形の重複によって入力外部輪郭線図形を構 成し得る成分図形を指す。入力図形は凸図形が重複し てできた図形であると規定しているため, 冗長な山図 形証無条件に結果から削除できる。従って結果を凸図 形と凹図形に分類し，凹図形のうち冗長なものを結果 から削除する。図 $8 て ゙ は(d)$ 図がこれに相当する。圥長 な凸図形が抽出された場合は，Gコード生成への応用 を想定すると加工結果に影響はないため，ここではす

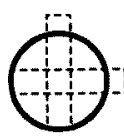

(a)

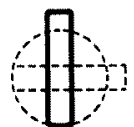

(b)

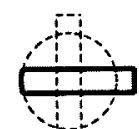

(c)

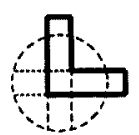

(d)
図 8 閉ループの抽出

Fig. 8. Extracted closed-loops. 


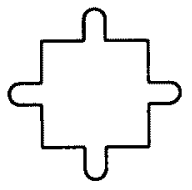

(a) 入力図面中の穴の形状

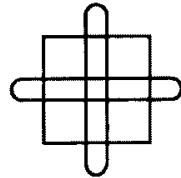
る加工要素への分解結果 （b）シルエット分脽㓳理に上

図 9 設計図面の加工要素への分解

Fig. 9. A decomposition of a design drawing into punch primitives.

ベて分離結果として残し，加工方法を決定する際に他 の制約(使用可能な工具の寸法や形状など)を用いて処 理することとする。例では, 入力から最終的に(a)〜 (c) 図の3 個の閉図形が分離結果として出力される。

以上の手続きで，NCTによる加工のための設計図 面に現れるようなほとんどの形状を処理できる。

\section{4. 図面認識モジュール}

製品の仕様として与えられる設計図面を入力し，そ の形状を認識するモジュールである。1回の打抜きで 加工できる単純な穴については，それが標準工具のう ちのどの形状に相当するかを識別する。複数回の打抜 きで加工する必要がある複雑な穴については, 前章で 述べた重複分離手続きを利用し，与えられた穴の形状 を輪郭線図形とみなし，これを加工要素に対応する成 分図形に妢離する。通常 NCT で加工するための設計 図面では，標準工具の組合せで加工できる形状のみが 含まれる。最終的に，分離された成分図形は標準工具 の形状に対応するので, 各成分図形ごとにどの形状に 相当するかを識別する。

重複分離手続きにより設計図面中の穴の形状を加工 要素に分解した例を図 9 に示寸。この例では，(a)図 の入力は, (b)図に示した一つの正方形と二つの長丸 に分解された。

このモジュールにおける処理では, 図形を形状とし てのみとらえるので，分解された加工要素は実際には 1 回の打抜きに相当するとは限らない。どのように加 工するかは次の Gコード生成モジュールで決定され る。その際に重複分離手続きにおける輪郭線であった か分離候補線であったか, すなわち図面中の外形線で あったかつけ加えた補助線であったかという情報が重 要となるので, 分解された加工要素はこの情報を含ん

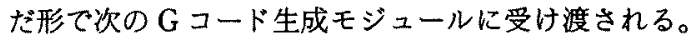

\section{5. プログラム生成モジュール}

このモジュールではまず，図面認識モジュールで分

\section{(a) 加工要少 (分解結果)}

(b) 使用可能な工具

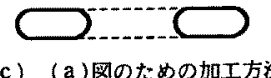

図 10 加工に使用する工具の選択

Fig. 10. Tool selection for punch.

解された各加工要素のデータから，それを加工するた めの Gコード 1 行を生成するという操作を行いプロ グラムの原型を作成する。ここでは, 使用可能な工具 をモデルとして，加工要素とモデルとの比較・照合に より加工に使用する工具を選択し，加工方法を決定す るために手続き的規則を利用する。次に生成された $\mathrm{G}$ コードの順序，すなわち加工の順序を決定する。

〈5・1〉 Gコードの生成 同じ形状を加工する場 合でも使用可能な工具によって加工戦略が異なる。そ のプログラムを用いて工作するときに使用できる工具 に関する情報がないと， Gコードを生成することはで きない。そこで, 使用可能な工具の種類および寸法を 工具データベースとしてあらかじめ準備する。この工 具データベース中から加工要素を加工するための工具 を選択し，打ち抜く点の座標値と使用工具のデータの 組に変換する。工具データベース中には使用可能な各 工具について, 工具の形状・寸法などの情報がそれぞ れ記述されている。

次に，加工方法を決定する規則の一例を述べる。図 面認識モジュールで分解した結果, 図 10（a）に示し た形状のような加工要素が得られた場合, 工具デー夕 ベース中に寸法が一致する工具が存在すれば，その工 具を使うように 1 行の $G$ コード（1 回の打抜きに相 当する）を生成する。しかし，そのような工具が存在 しなかった場合には，外形線（図中実線）と内部輪郭 線（図中破線）に注目して，少なくとも外形線の部分 は加工することができる工具を選択し，それを使った

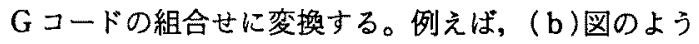
な寸法の工具がデータベース中にあれば，(c)図のよ うに 2 回の打抜きによって (a)図中の外形線（実線部 分）の形状をすべて加工できるのて，この 2 回のパン

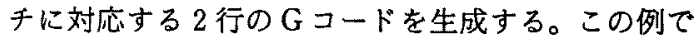
は, 同じ工具を 2 回使ったが, 加工要素の形状によっ

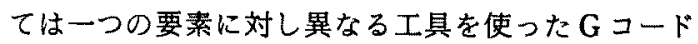
行を生成する場合もある。

このような, 加工方法決定のための規則には，図 


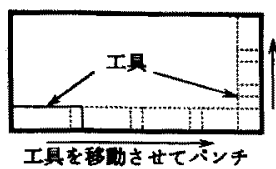

(a) 角のニフリング

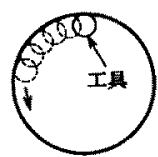

(b) 丸かニプ1)ング
図 11 ニブリング加工の例

Fig. 11. Machining method with nibbling.

11 に示すような，寸法の大きい角および丸に対する ニブリング加工（寸法の小さな工具を移動させながら 多数のパンチでーつの穴を加工する方法) で処理する ような規則も用意している。他の規則を適用すること がでなかった場合には，可能な限りニフリング加工 のGコードを生成する。

〈5・2〉加工順序の決定 加工順序は, 加工精度 抒よび加工時間に影響を与える重要な要素てある。一 連の Gコードが生成された後，プログラム中の Gコ 一ドの順序を適切に並べ換えて, 最終的にNC加工 プログラムとして出力する。加工順序に関して，幾つ かの経験的な規則がある。例えば，加工精度に関して は,

(i) 小さい穴から順次大きな穴を開けていく。

（ii）同じ大きさの場合，角より丸を先に開ける。 などである。また，加工時間を短縮するために，

(i) 図面の右上から加工を開始し，なるべく短い 経路で再び右上に戻るようにする。

（ii）工具の変更回数をできるだけ少なくする。 などの規則がある。このような規則を用いた手続き的 な処理によって加工順序を決定する。

\section{6. 実行結果}

図面認識モジュールおよびプログラム生成モジュー ルはいずれもLisp 語語を用いてエンジニアリングワ 一クステーション上に実装した。また，シミュレーシ ヨンツールはX ウィンドウシステムを利用して C 言 語により作成した。

〈6・1〉システムの実行結果 図 12 に示すCAD 図面データを入力してシステムで処理し生成された $\mathrm{G}$ コードプログラムを用い, シミュレーションツールに よって加工の様子を表した結果が図 13 である。

図13中で，左上および右上の丸と長丸二つ，中央 の角と長丸四つ，下左と下中央扔よび下右の丸と角， のそれぞれの組合せで加工される穴が，重複分離を利 用した図面認識により処理された部分である。

処理に要する時間は, 速度約 3 MIPS のエンジニア リングワークステーションで処理した場合, 図 12 の

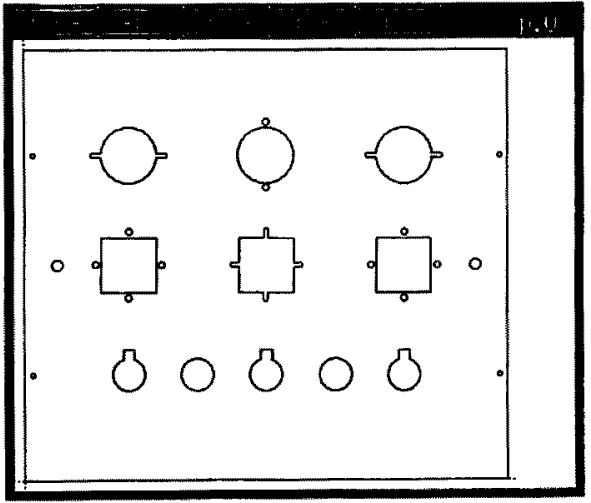

図 12 入力図面データ

Fig. 12. An input drawing data.

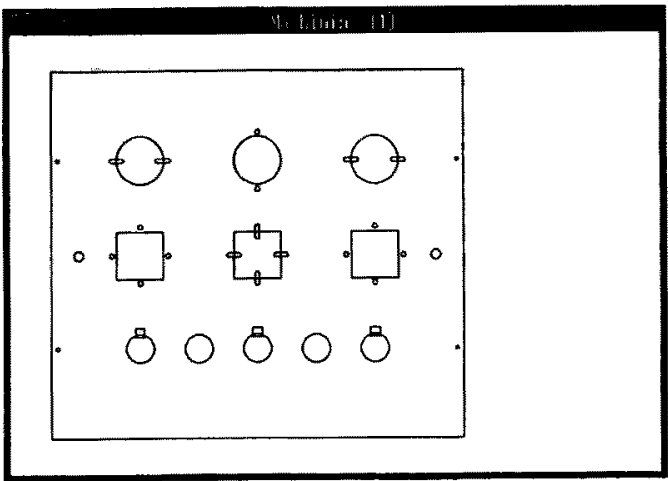

図 13 シミュレーション結果

Fig. 13. The output of the simulated result.

例では図面認識モジュールが約 5 分, プログラム生成 モジュールが約 2 分である。熟練したプログラマが手 作業で行った場合，このような簡単な例でもコーディ ングからプログラムの入力を終えるまで，少なくとも 約 1 時間は要する。そのうえ手作業では単純な間違い が発生する可能性もあり、デバッグまで考慮すると更 に時間が必要である。人間が行う場合と比較すれば, 本システムを用いることにより特に複雑な加工になる ほど，顕著に時間短縮が可能となろう。

〈6・2〉 シミュレーションッール 前節では結果 の表示にシミュレーションツールを用いたが，これ以

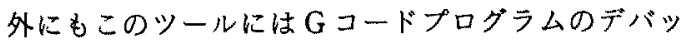
グのために有用な機能をもたせている。具体的には次 の機能を備えている。

(i) 加工結果の表示

(ii） 加工の 1 ステップ実行 


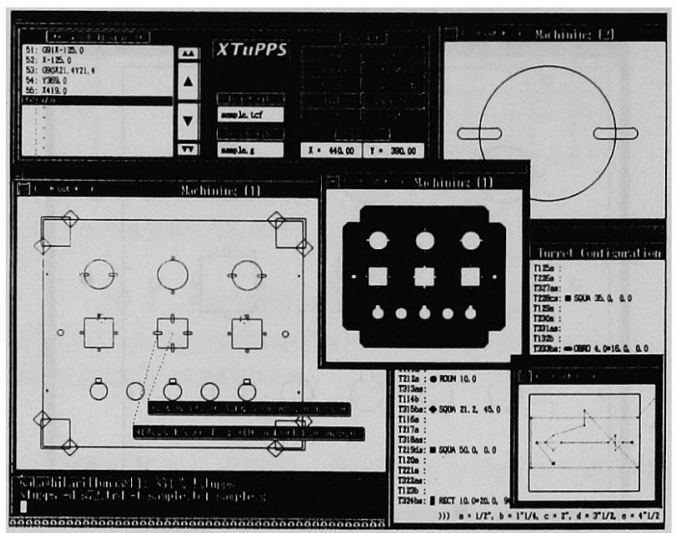

図 14 シミュレーションツールの操作画面 Fig. 14. Display image of the simulation tool in operation.

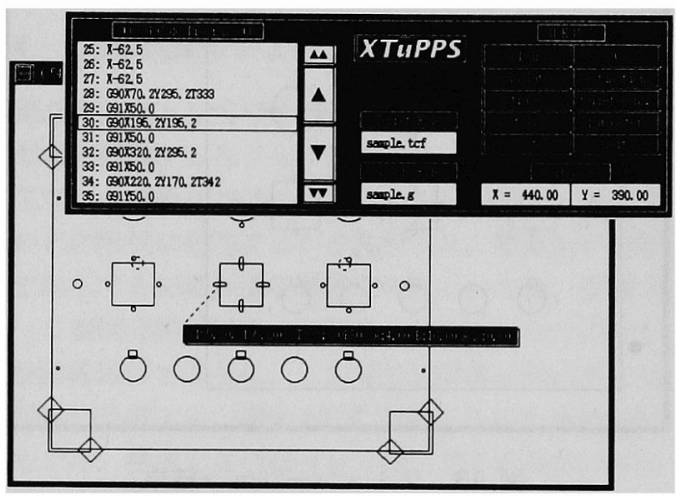

図 15 シミュレーションツールによる加工 情報の表示

Fig. 15. Display image of the information about machining by simulation tool.

（iii） 部分拡大表示

（iv）穴の形状/製品形状の表示切換え

(V) 加工順序の表示

（vi） 表示画面上での穴に関する加工情報の表示

(vii）タレット中の工具の配置の表示

図 14 にシミュレーションツールの操作画面の例を 示す。

このツールは，Xウィンドウ上に表示され，主な 操作はマウスによる指示のみで行うことができる。例 えば, 図 15 のように, 表示画面中の任意の穴の位置 でマウスをクリックすると，その穴に関する加工情報 を表示させることができる。更に，その穴が $\mathrm{Gコー}$ ドプログラムのどの行に対応しているのかをプログラ ム表示ウィンドウと同期して見つけることができる。
図 15 の例では，加工情報を表示している長丸の穴は, プログラム中の 30 行目の G コードによって加工され たことを示している。

このほか，必要に応じて新たにウィンドウを開いて 表示するなど, マルチウィンドウシステムの特徴を生 かして操作性の向上を図っている。このシミュレーシ ヨンツールを用いることにより, 操作者は容易に G コードプログラムの微少な変更・修正を行うことがで き, 自動生成システムによるプログラム生成処理のみ では不十分な部分を人間が補うことができる。

\section{7. むすび}

本研究では, 図面の認識に重複分離手法を用いた NC 加エプログラム自動生成システムを提案し, これ を実現したシステムによる実行結果を示した。また, シミュレーションツールを併せて用いることにより， 自動生成システムにより生成された結果では不都合な 点を, 人間の判断により手を加えてプログラムの修正 を可能にしたため，実用性が高まったと考えられる。 これにより, 工作時の精度や時間などに微妙に影響す る部分にプログラマが蓄積してきたエキスパート知識 を容易に反映させることができる。このことは，自動 化のための柔軟なシステムの実現例ということができ よう。

本システムを用いることにより，処理時間について も手作業でプログラムを作成する場合と比して格段に 短縮できるため，プログラム生産性の向上に貢献する ものと思われる。

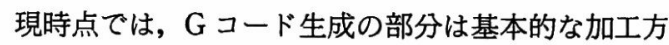
法のみに対応しているが，更に規則を加えることによ り実際の生産における多様な加工に対応できるものと 考える。

(平成 4 年 8 月 25 日受付)

\section{文献}

（1）島谷 明·鋀沢 勇：「図形分節における分節候補の自動抽出 法に関する研究」, 電子情報通信学会「画像処理の高度化と 高速化」シンポジウム講演論文集, p. 197 (平元)

(2) L. R. Williams: "PERCEPTUAL ORGANIZATION OF OCCLUDING CONTOURS", Image Understanding Work shop, Sponsored by DARPA Information Science and Technology Office, p. 639 (1990)

（3）長尾智晴・安居院猛・中嶋正之：「部分形状特徵を用いた相似 図形の抽出手法」，信学技報，PRU 88-67 (昭 63)

（4）中村裕一・長尾 真:「重なりあった二次元形状の認識」, 人 工知能学誌, 3, No. 4, 461 (昭 63-7)

（5）安藤和久・杉江 昇：「主観的輪郭の生成アルゴリスム」，信 学技報, PRU 86-68 (昭 61))

（6）安田浩之・安藤和久・大西 昇・杉江 昇：「物理的に存在し ない輪郭線の抽出」, 信学論 (D II), J73-D-II, 906 (平 26)

（7）北橋忠宏・尹 巨棟・古林 貴:「シルエットによる対象物認 識」, 信学技報, PRU 89-100 (平 2) 
（8）若林伸和・御牧 義:「NC工作機械プログラム作成支援シス テム」, 平元人工知能学会全大(第 3 回) II, p. 657

(9) N. Wakabayashi, N. Honda, T. Mimaki \& S. Matsumoto: "A SUPPORTING SYSTEM FOR MAKING NC PRO. GRAMS BY WAY OF KNOWLEDGE ENGINEERING APPROACH", Proc. IFAC Skill Based Automated Production Symposium, Int. Federation of Automatic Control, p. 213 (1989)

（10）若林伸和・安部愳広・北橋忠宏：「NC加エプログラム自動生 成システム」, 情報処理学会第 41 回 (平 2 後期) 全大 $(6)$, p. 301

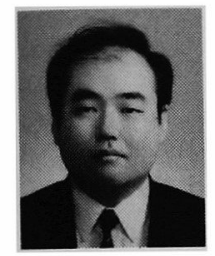

\section{若 林 伸 和 (正員)}

昭和 40 年 3 月 30 日生。平成元年 3 月 電気通信大学大学院修士課程修了。4 年 3 月大阪大学大学院工学研究科博士課程 単位取得退学。同年 4 月電気通信大学大
学院情報システム学研究科助手, 現在に至る。主として, 人工知能システムの作成に関する研究に従事。情報処理学 会, 人工知能学会, 日本航海学会, 電子情報通信学会会 員。

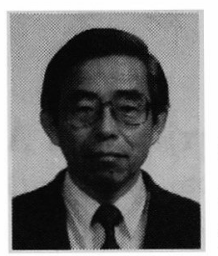

\section{北 橋 忠 宏 (非会員)}

昭和 14 年 1 月 23 日生。 43 年大阪大 学大学院博士課程修了。同年同大学基礎 工学部助手。53 年豊橋技術科学大学助 教授, 同教授を経て, 61 年大阪大学産 業科学研究所教授, 現在に至る。人工知能, 特に物体認識 に関する研究に従事。工学博士。電子情報通信学会, 情報 処理学会, 人工知能学会, IEEE, 計量国語学会会員。 